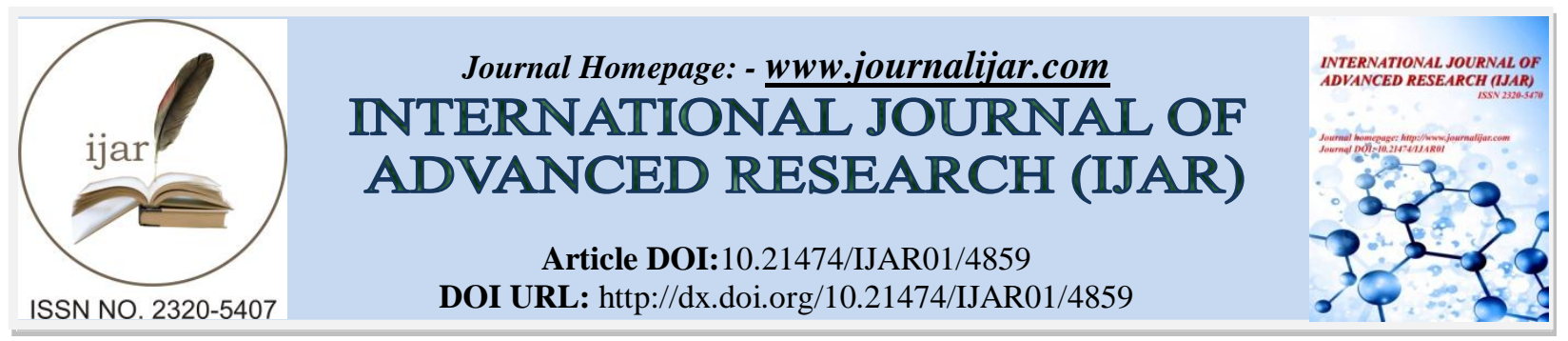

RESEARCH ARTICLE

\title{
EVALUATION OF ANTINEPHROLITHIC ACTIVITY OF BENINCASA HISPIDA (THUNB) COGN. IN WISTAR ALBINO RATS AGAINST ETHYLENE GLYCOL INDUCED NEPHROLITHIASIS.
}

\section{"Qadrie $\mathbf{Z L}{ }^{1}$, Humaira $\mathbf{A}^{\mathbf{2}}$ and Anandan $\mathbf{R}^{3}$.}

1. Professor and Head, Department of Pharmacology and Toxicology, Pratishta Institute of Pharmaceutical Sciences, Durajpally, Hyderabad, Telangana.

2. Ph.D. Scholar, Dept of Animal Nutrition, Faculty of Veterinary Sciences and Animal Husbandry, Sher I Kashmir University of Agricultural Sciences \& Technology-Kashmir, Srinagar, J\&K.

3. Professor and Head, Department of Pharmacology \& Toxicology, Vinayaka Mission's College of Pharmacy, Salem, Tamil Nadu.

\section{Manuscript Info}

Manuscript History

Received: 15 May 2017

Final Accepted: 17 June 2017

Published: July 2017

Key words:-

Nephrolithic, Kidney Stones, Ethylene

glycol, Benincasa hispida

\section{Abstract}

Purpose: To evaluate the activity of Nephrolithic of the aqueous and ethanolic extracts of Benincasa hispida (Thunb.)COGN seeds against ethylene glycol induced Nephrolithiasis in albino rats.

Methods: Nephrolithiasis was induced by oral administration of ethylene glycol $(0.75 \% \mathrm{v} / \mathrm{v})$ in male albino rats for 28 days. The ethanolic and aqueous extracts of seeds of Benincasa hispida (250 \& $500 \mathrm{mg} / \mathrm{kg}$ ) were administered orally from the 28 days as a curative regimen urine analysis; serum analysis and histopathological study were performed.

Results: The body weight changes were noted EG treated animals shown marked weight loss when compared to control. Treated groups like cystone at dose level of $750 \mathrm{mg} / \mathrm{kg}$ body weight, EESBH and $A q$. $E S B H$ at dose levels of 250 and $500 \mathrm{mg} / \mathrm{kg}$ body weight showed marked recovery in weight loss when compared to EG treated group. The urine volume, urine were decreased as well as oxalates, calcium, phosphorus, sodium and potassium excretion in urine, serum urea, uric acid, creatinine and BUN contents were increased in lithiatic group as compared to normal control group. Treatment with both ethanolic and aqueous seed extracts restored urine volume, oxalates, calcium, phosphorus, sodium and potassium levels. Histopathological examination revealed tubular degeneration, dilatation, presence of $\mathrm{CaOx}$ crystals in the lumen of renal tubules and intense interstitial mononuclear cell infiltration in the lithiatic control group. These histopathological alterations were markedly regressed in other treated groups.

Conclusions: The results demonstrate that the ethanolic and aqueous extracts of Benincasa hispida seeds have potent anti-nephrolithiatic activity against nephrolithiasis induced by ethylene glycol in wistar albino rats.

Copy Right, IJAR, 2017,. All rights reserved.

Corresponding Author: - Dr. Qadrie ZL. 


\section{Introduction:-}

The formation of crystal aggregates in the urinary tract results in kidney stones, the clinical condition referred to as Nephrolithiasis. Kidney stones may produce no symptoms or may be associated with one or several of the following: flank pain, gross or microscopic hematuria, obstruction of one or both kidneys, and urinary infections. The stones are usually formed by one of four substances:

a. Calcium,

b. Uric acid,

c. Magnesium ammonium phosphates (or struvite)

d. Cystine [1].

Occasionally, calcium salts and uric acid will be present in the same stone. Some very rare types of kidney stones include xanthine and triamterene stones, which are seen in individuals taking xanthine oxidase inhibitors and triamterene-containing diuretics, respectively. Indinavir stones have been reported in HIV patients treated with this retroviral therapy [2].

The overall Probability of forming stones varies in different parts of the world. The risk of developing nephrolithiasis in normal adults appears to be lower in Asia (1-5\%) than Europe (5-9\%) and North America (12\% in Canada, $13 \%$ in USA). The highest risk was reported in Saudia Arabia (20.1\%) [3].

Ethylene glycol (EG) being a chief substitute for alcohol; EG is commonly used as anti freeze in cooling systems of automobiles, aircrafts and has wide industrial applications. Many accidental deaths due to its poisoning have been reported $[4,5]$. Toxicity from EG is produced from the metabolites such as glycoaldehyde, glyoxalate and oxalate, producing wide spread tissue injury in the kidney. Patients die of acute renal failure due to EG toxicity [6]. Man and his domesticated animals have been largely dependent on plants for the essentials of their existence by way of food, clothing, shelter and medicines etc, since the time immemorial [7].

The demand for Ayurvedic /herbal drugs/ phyto-medicines is increasing day by day globally [8]. Ancient literature has prescribed various herbs for the cure of kidney disease. The term "Pashanabeda" has been cited in the literature to identify a group of plants, which have been extensively, used in the indigenous system of medicine to dissolve urinary calculi and stones. Benincasa hispida (Thunb) COGN. is employed traditionally to treat disorders such as dry-cough, fever, urethral discharges, kidney stones, biliousness and thirst. It acts as brain tonic and also possesses anti-helminthic property. In China, it is used in the treatment of appendicitis. Oil from seeds is soporific, good for the brain and liver and effective in the treatment of syphilis. Seed ash is a prized remedy for gonorrhea; ash is applied to painful wounds and swellings [9-11]. The present study was carried out to scientifically prove some of the folkloric use of this plant in conditions of Nephrolithiasis by exploring antinephrolithic activity.

\section{Materials and Methods:-}

The ethanolic extracts of seeds of Benincasa hispida (THUNB) COGN. [EESBH] (250 and $500 \mathrm{mg} / \mathrm{kg} \mathrm{body}$ weight), aqueous extracts of seeds of Benincasa hispida (THUNB) COGN. [Aq. ESBH] (250 and $500 \mathrm{mg} / \mathrm{kg}$ body weight) were used as test dose and standard drug cystone (750 mg/kg body weight) were used and Ethylene glycol $(0.75 \%)$ was used as toxic control.

\section{Chemicals and Reagents:-}

Ethylene glycol (EG) (Merck Laboratories, Mumbai, India), Cystone tablets (The Himalaya Drug Company, Bangalore, India).

\section{Ethylene Glycol Induced Nephrolithiasis:-}

Ethylene glycol induced hyperoxaluria model was used to assess the nephrolithic activity in albino rats following procedures as under. Animals were divided into 7 groups containing 6 animals in each. Group I served as a vehicle treated control and maintained on regular rat food and drinking water ad libitum. All the remaining groups (Groups VI) received calculi inducing treatment, comprised of ethylene glycol $(0.75 \% \mathrm{v} / \mathrm{v})$ in drinking water ad libitum for 15 days to accelerate lithiasis. Groups III treated with cystone (500 mg/kg body wt.) and Group IV and V were treated with $E E S B H$ at doses of 250 and $500 \mathrm{mg} / \mathrm{kg}$ body wt. and Group VI and VII were treated with $A q$. ESBH at doses of 250 and $500 \mathrm{mg} / \mathrm{kg}$ body wt. from day 1 to day 15 of calculi induction, respectively. Extracts and standard drug were suspended in distilled water and given by gastric intubation once daily. Urine was collected on the $28^{\text {th }}$ day 
for $24 \mathrm{~h}$ by keeping the animals in polypropylene metabolic cages. The collected urine was analyzed for calcium, oxalates, phosphorus, sodium and potassium using standard methods. The volume of urine collected from all groups was recorded. The rats were sacrificed by cervical dislocation after $24 \mathrm{~h}$ of above treatment. The blood was collected by cardiac puncture and the serum uric acid, blood urea nitrogen (BUN), creatinine and urea levels were estimated. Finally, the prevalence of lithiasis was confirmed by histopathological studies of the kidneys isolated from the sacrificed animals.

\section{Urine Analysis:-}

At the end of the experiment (on day 28), all animals were kept in metabolic cages individually for the collection of 24-hour urine samples. $3 \mathrm{~N} \mathrm{HCl}$ was added to the urine samples, followed by a 10 -minute centrifugation at 1,500 rpm. The supernatant and debris were discarded and the samples were kept at $-20^{\circ} \mathrm{C}$. A Chemwell Biochemistry automatic analyzer (Awareness Technology, Inc., Palm City, FL, USA) was used for oxalate, calcium, phosphorus, sodium and potassium measurement in urine.

\section{Histopathological studies:-}

The isolated kidneys were weighed and transferred to $10 \%$ neutralized formalin (pH 7.4). Pathological changes were observed in the sections of kidney fixed in paraffin that were stained with hematoxylin and eosin.

\section{Statistical Analysis:-}

Results were expressed as Mean \pm Standard Error of Mean (SEM). The data was analyzed using student's t-test and $\mathrm{P}<0.05$ was considered statistically significant.

\section{Result and Discussion:-}

The ethanolic and aqueous seed extracts of Benincasa hispida were tested at 250 and $500 \mathrm{mg} / \mathrm{kg}$ doses for Nephrolithic Activity. Both the extracts produced significant changes in body weights, urine output and urine parameters like oxalates, calcium, phosphorus, sodium and potassium levels in dose dependent manner. The ethanolic and aqueous extracts at dose level of $500 \mathrm{mg} / \mathrm{kg}$ produced more significant reduction urine parameters than that of the other two lower dose levels of extracts shown in table no $1 \& 2$.

Ethanolic and Aqueous seed extracts of Benincasa hispida produced significant changes blood serum parameters like urea, uric acid, Creatinine and BUN levels in dose dependent manner. The ethanolic and aqueous extracts at dose level of $500 \mathrm{mg} / \mathrm{kg}$ produced more significant reduction urine parameters than that of the other two lower dose levels of extracts shown in table no 3 .

Histopathological studies of the kidneys of rats treated with ethylene glycol showed marked degenerative changes of living epithelium and narrowing of tubules, which indicates the damage of kidney by ethylene glycol. The $E E S B H$ extract at $500 \mathrm{mg} / \mathrm{kg}$ dose level has shown more significant activity than the Aq. ESBH extract.

The alterations in membrane lipid and protein resulting from peroxidation can lead to increased permeability of calcium resulting in a loss of enzyme activity. Decreased $\mathrm{Ca}^{2+}$ ATPase activity was noted in the kidneys of patients with nephrolithiasis [12]. Upon treatment with ethanolic and aqueous seed extracts of Benincasa hispida $250 \mathrm{mg}$ and $500 \mathrm{mg}$, there was an elevation in the levels of calcium in both curative groups when compared to control and this effect was dose dependant. In this study 28 days administration of $0.75 \%(\mathrm{v} / \mathrm{v})$ ethylene glycol induced nephrotoxicities. These toxicities were characterized by marked elevation of blood serum creatinine and oxalates are remarkable decrease to normal value by treating with ethanolic and aqueous seed extracts of Benincasa hispida at doses of 250 and $500 \mathrm{mg} / \mathrm{kg}$ body weight. Prophylactic treatment was showing more treating efficiency than curative treatment.

The ethanolic seed extract of Benincasa hispida were tested at 250 and $500 \mathrm{mg} / \mathrm{kg}$ doses for gentamicin induced renal injury and free radical scavenging effect on DPPH, ABTS, Super oxide, Nitric oxide, and TBARS and Ferric ion free radicals at dose level of 250 and $500 \mathrm{mg} / \mathrm{kg}$ body weight shown protective effects against gentamicininduced nephrotoxicity in rat [13].

In case nephrolithiasis, elimination of the normal electrolytes like sodium and potassium will be reduced due to the deposition of crystals in distal tubule of the kidney where these parameters will get excreted. Hence due to the reduced elimination serum level of these normal electrolytes will be elevated. In our present investigation reveals 
that ethanolic and aqueous seed extracts of Benincasa hispida 250 and $500 \mathrm{mg}$ doses increases the electrolyte elimination and hence reduced their blood levels to normal.

Microscopic examination using polarized light of kidney sections derived from nephrolithiatic rats showed intratubular and interstitial crystal deposits consistent with the findings of others. In the present investigation histopathological evaluation showed the maximum prevention of crystal deposition at the preventive study which may be due to the active compounds which is present in various doses of ethanolic and aqueous seed extracts of Benincasa hispida. Ethanolic extract of Benincasa hispida has high antioxidant capacity may be due to the presence of important phytoconstituents like phenolic compounds, steroids and flavanoids may be prevents the calcium oxalate crystal deposition in the kidney by preventing hyperoxaluria induced peroxidative damage to the renal tubular membrane surface which in turn can prevent calcium oxalate crystal attachment and subsequent development of kidney stones [14]. In the present investigation ethanolic and aqueous seed extracts of Benincasa hispida at dose levels of $250 \mathrm{mg}$ and $500 \mathrm{mg} / \mathrm{kg}$ body weight shows potent antinephrolithic activity may be due to their antioxidant activity.

Table No. 1:-Antinephrolithic activity of Benincasa hispida in wistar albino rats against ethylene glycol induced nephrolithiasis on body weight changes and Urine output.

\begin{tabular}{|c|c|c|}
\hline Experimental Groups & Body weight changes & Urine output \\
\hline Normal & $195.00 \pm 4.84$ & $12.16 \pm 0.83$ \\
\hline Ethylene glycol $(0.75 \%)$ & $165.50 \pm 3.51^{*}$ & $5.97 \pm 0.71^{*}$ \\
\hline Cystone $500 \mathrm{mg} / \mathrm{Kg}$ & $188.10 \pm 4.03^{*}$ & $11.86 \pm 0.35^{*}$ \\
\hline EESBH $500 \mathrm{mg} / \mathrm{Kg}$ & $181.16 \pm 4.18^{*}$ & $10.01 \pm 0.06^{*}$ \\
\hline EESBH $250 \mathrm{mg} / \mathrm{Kg}$ & $176.16 \pm 4.20^{*}$ & $8.05 \pm 0.27^{*}$ \\
\hline Aq. ESBH $500 \mathrm{mg} / \mathrm{Kg}$ & $179.16 \pm 4.40^{*}$ & $9.15 \pm 0.07^{*}$ \\
\hline Aq. ESBH $250 \mathrm{mg} / \mathrm{Kg}$ & $174.16 \pm 4.30^{*}$ & $7.95 \pm 0.29$ \\
\hline
\end{tabular}

Values are expressed as Mean \pm SEM, $\mathrm{n}=6$. $*$ Significantly different from the Normal at $\mathrm{P}<0.05$

EESBH- Ethanolic extract of seeds of Benincasa hispida; Aq. ESBH- Aqueous extract of seeds of Benincasa hispida

Table No. 2:-Antinephrolithic activity of Benincasa hispida in wistar albino rats against ethylene glycol induced nephrolithiasis on Urine Parameters.

\begin{tabular}{|c|c|c|c|c|c|}
\hline Experimental Groups & $\begin{array}{c}\text { Oxalate } \\
(\mathbf{m g} / \mathbf{d L})\end{array}$ & $\begin{array}{c}\text { Calcium } \\
(\mathbf{m g} / \mathbf{d L})\end{array}$ & $\begin{array}{c}\text { Phosphorus } \\
(\mathbf{m g} / \mathbf{d L})\end{array}$ & $\begin{array}{c}\text { Sodium } \\
(\mathbf{m g} / \mathbf{d L})\end{array}$ & $\begin{array}{c}\text { Potassium } \\
(\mathbf{m g} / \mathbf{d L})\end{array}$ \\
\hline Normal & $0.46 \pm 0.05$ & $1.43 \pm 0.11$ & $4.32 \pm 0.23$ & $119.20 \pm 2.25$ & $5.08 \pm 0.08$ \\
\hline Ethylene glycol $(0.75 \%)$ & $4.97 \pm 0.19^{*}$ & $5.09 \pm 0.19^{*}$ & $8.67 \pm 0.39^{*}$ & $151.30 \pm 1.88^{*}$ & $6.15 \pm 0.07^{*}$ \\
\hline Cystone $750 \mathrm{mg} / \mathrm{Kg}$ & $0.63 \pm 0.07^{*}$ & $1.63 \pm 0.11^{*}$ & $4.44 \pm 0.19^{*}$ & $123.00 \pm 2.81^{*}$ & $5.28 \pm 0.10^{*}$ \\
\hline EESBH 500 mg/Kg & $2.04 \pm 0.15^{*}$ & $2.62 \pm 0.37^{*}$ & $4.87 \pm 0.19^{*}$ & $126.40 \pm 3.00^{*}$ & $5.21 \pm 0.07^{*}$ \\
\hline EESBH 250 mg/Kg & $3.11 \pm 0.17^{*}$ & $3.90 \pm 0.19^{*}$ & $5.64 \pm 0.51^{*}$ & $136.50 \pm 3.78^{*}$ & $5.75 \pm 0.15^{*}$ \\
\hline Aq. ESBH 500 mg/Kg & $2.84 \pm 0.13^{*}$ & $2.92 \pm 0.39^{*}$ & $5.01 \pm 0.22^{*}$ & $127.31 \pm 3.10^{*}$ & $5.23 \pm 0.08^{*}$ \\
\hline Aq. ESBH 250 mg/Kg & $3.61 \pm 0.11^{*}$ & $4.19 \pm 0.22^{*}$ & $6.0 \pm 0.61^{*}$ & $138.21 \pm 3.80^{*}$ & $5.88 \pm 0.16^{*}$ \\
\hline
\end{tabular}

Values are expressed as Mean \pm SEM, $\mathrm{n}=6$. $*$ Significantly different from the Normal at $\mathrm{P}<0.05$

EESBH- Ethanolic extract of seeds of Benincasa hispida; Aq. ESBH- Aqueous extract of seeds of Benincasa hispida

Table No. 3:-Antinephrolithic activity of Benincasa hispida in wistar albino rats against ethylene glycol induced nephrolithiasis on blood parameters.

\begin{tabular}{|c|c|c|c|c|}
\hline Experimental Groups & Urea (mg/dL) & Uric acid (mg/dL) & Creatinine (mg/dL) & BUN (mg/dL) \\
\hline Normal & $38.11 \pm 0.96$ & $1.73 \pm 0.13$ & $0.86 \pm 0.05$ & $41.24 \pm 0.80$ \\
\hline Ethylene glycol $(0.75 \%)$ & $49.99 \pm 0.96$ & $4.64 \pm 0.41$ & $1.54 \pm 0.37$ & $149.28 \pm 0.17$ \\
\hline Cystone $500 \mathrm{mg} / \mathrm{Kg}$ & $37.78 \pm 0.68$ & $1.95 \pm 0.14$ & $0.84 \pm 0.08$ & $42.10 \pm 0.77$ \\
\hline EESBH $500 \mathrm{mg} / \mathrm{Kg}$ & $40.38 \pm 0.44$ & $2.38 \pm 0.35$ & $1.08 \pm 0.13$ & $45.09 \pm 0.87$ \\
\hline EESBH $250 \mathrm{mg} / \mathrm{Kg}$ & $43.44 \pm 0.72$ & $3.01 \pm 0.11$ & $1.24 \pm 0.21$ & $48.30 \pm 0.67$ \\
\hline Aq. ESBH $500 \mathrm{mg} / \mathrm{Kg}$ & $41.08 \pm 0.34$ & $2.78 \pm 0.35$ & $1.28 \pm 0.11$ & $46.29 \pm 0.86$ \\
\hline Aq. ESBH $250 \mathrm{mg} / \mathrm{Kg}$ & $44.24 \pm 0.27$ & $3.81 \pm 0.19$ & $1.54 \pm 0.15$ & $49.49 \pm 0.57$ \\
\hline
\end{tabular}

Values are expressed as Mean \pm SEM, $\mathrm{n}=6$. ${ }^{*}$ Significantly different from the Normal at $\mathrm{P}<0.05$ 
EESBH- Ethanolic extract of seeds of Benincasa hispida; Aq. ESBH- Aqueous extract of seeds of Benincasa hispida

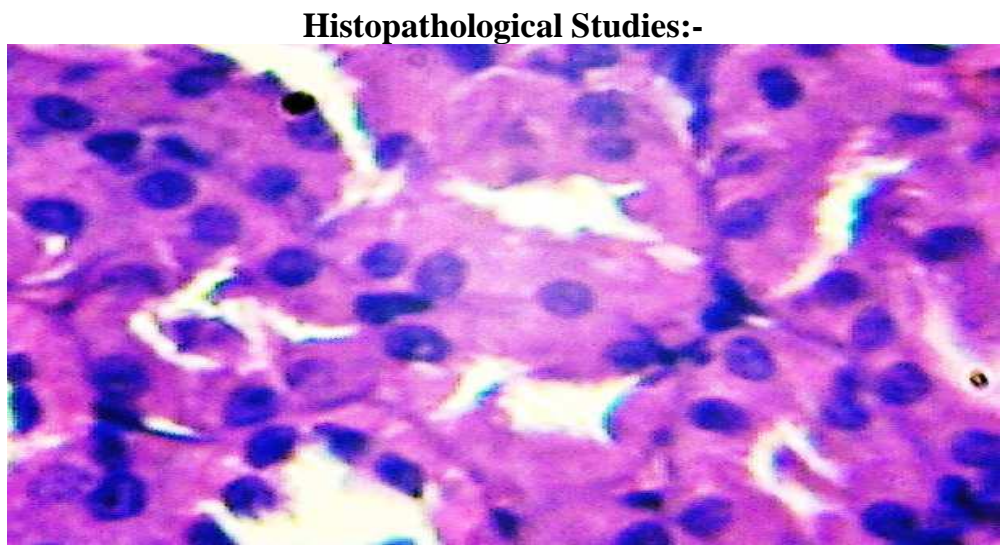

Control animals: Figure 1:-A sectional representation of normal rat kidney at $\mathrm{x} 400$ magnification (Haematoxylin and Eosin stain) showing normal glomeruli (GL) with an intact Bowman's capsule (BM), proximal convoluted (CT) and distal convoluted (DT) tubules

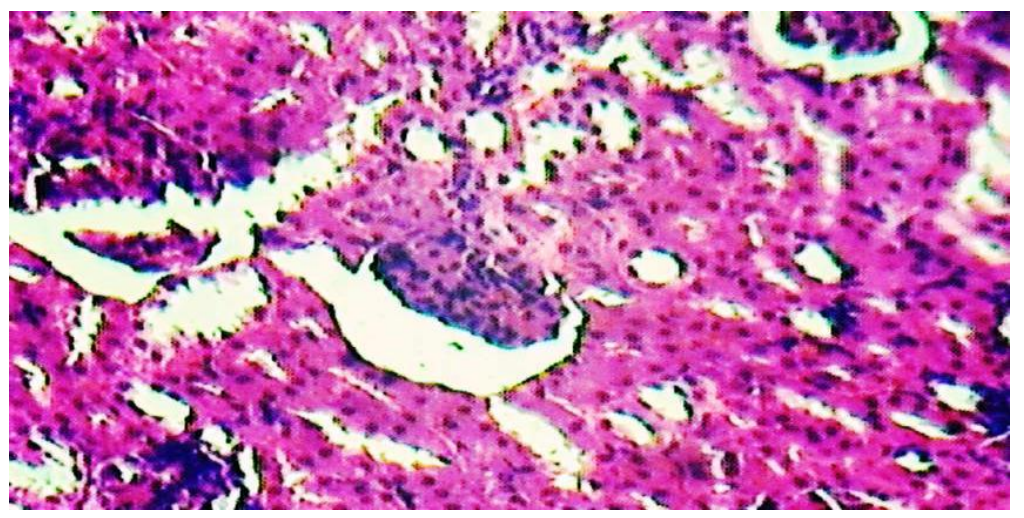

Negative control Figure 2:-A representative section of EG-intoxicated rat kidney at $\mathrm{x} 400$ magnification (Haematoxylin and Eosin) shows severe hydropic glomerular degeneration (GLH) obliterated proximal convoluted tubular lumen (OPC) and obliterated distal convoluted tubular lumen (ODC). The tubular lumens were completely obliterated and filled with fluid and casts.

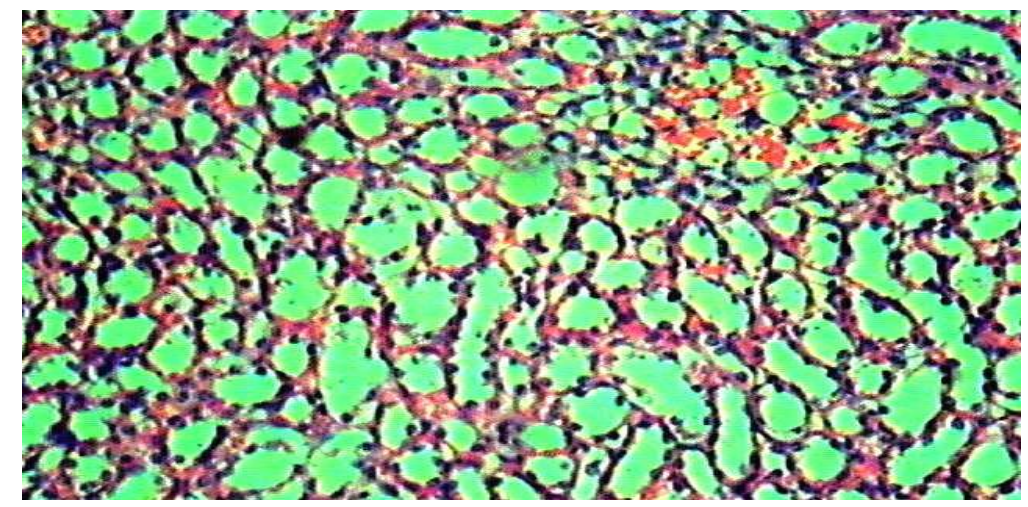

Standard drug treated Figure 3:-A sectional representation of normal rat kidney at x400 magnification (Haematoxylin and Eosin stain) showing normal glomeruli (GL) with an intact Bowman's capsule (BM), proximal convoluted (CT) and distal convoluted (DT) tubules 


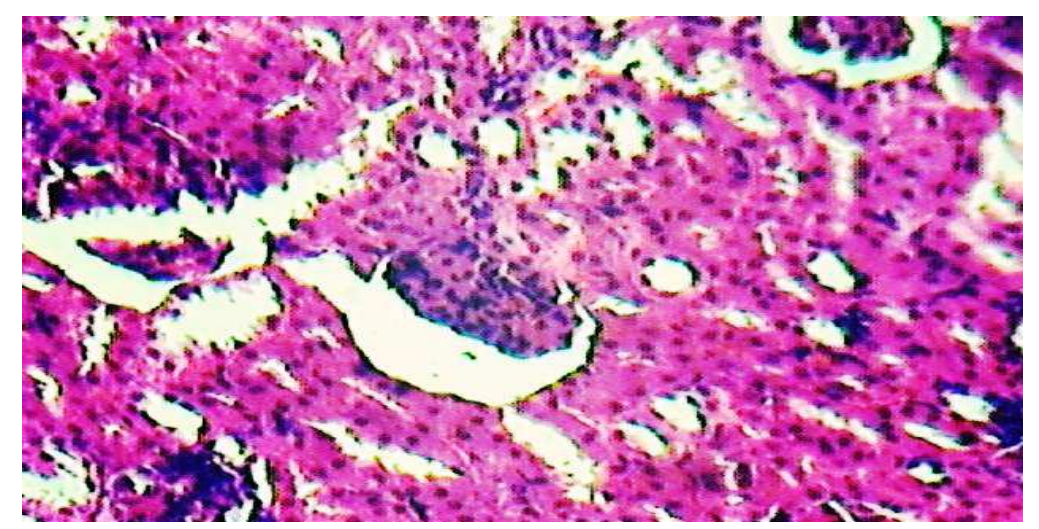

Figure 4:-A sectional representation of $250 \mathrm{mg} / \mathrm{kg} / \mathrm{day}$ EESBH pretreated, EG-intoxicated rat kidney at $\mathrm{x} 400$ magnification (Haematoxylin and Eosin) shows mesengial proliferation (MP) with thinning out of the Bowman's capsule (BM). There is mild tubular cast deposition (MTC) interposed with normal proximal convoluted tubule (PC) and distal convoluted tubule (DC)

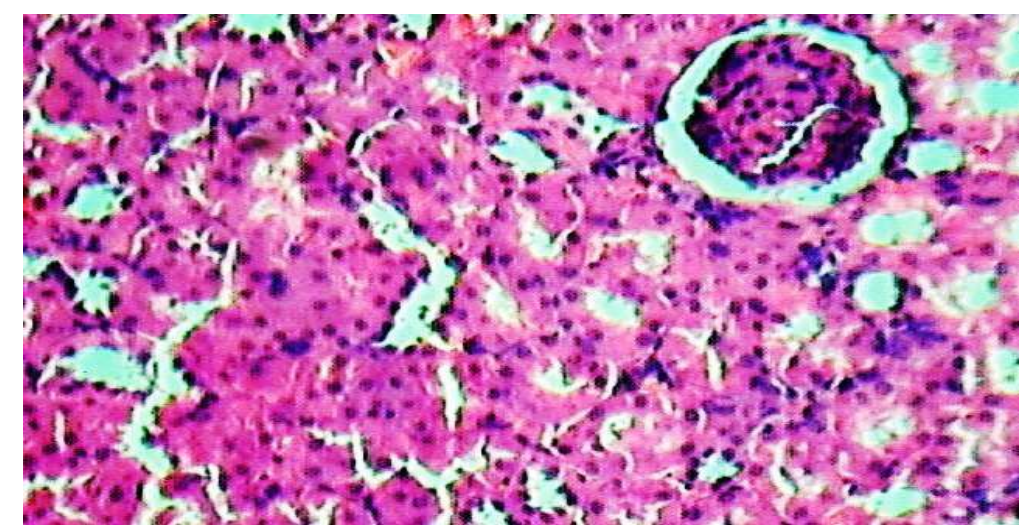

Figure 5:-A sectional representation of $500 \mathrm{mg} / \mathrm{kg} / \mathrm{day}$ EESBH pretreated, EG-intoxicated rat kidney at $\mathrm{x} 400$ magnification (Haematoxylin and Eosin) showing normal glomeruli (GL) encapsulated by normal Bowman's capsule (BM). There is no obvious tubular cast deposition

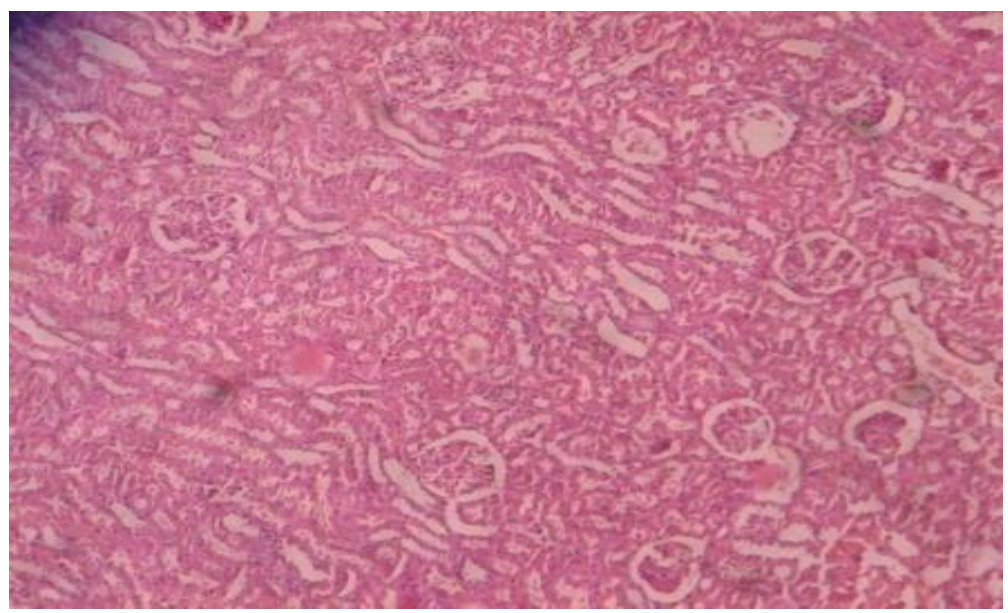

Figure 6:-A representative section of $250 \mathrm{mg} / \mathrm{kg} /$ day Aq. ESBH pretreated, EG-intoxicated rat kidney at x400 magnification (Haematoxylin and Eosin) shows moderate hydropic glomerular (GLM) and tubular degenerations (TD). The tubular lumens were moderately filled with fluid and casts (MTC) 


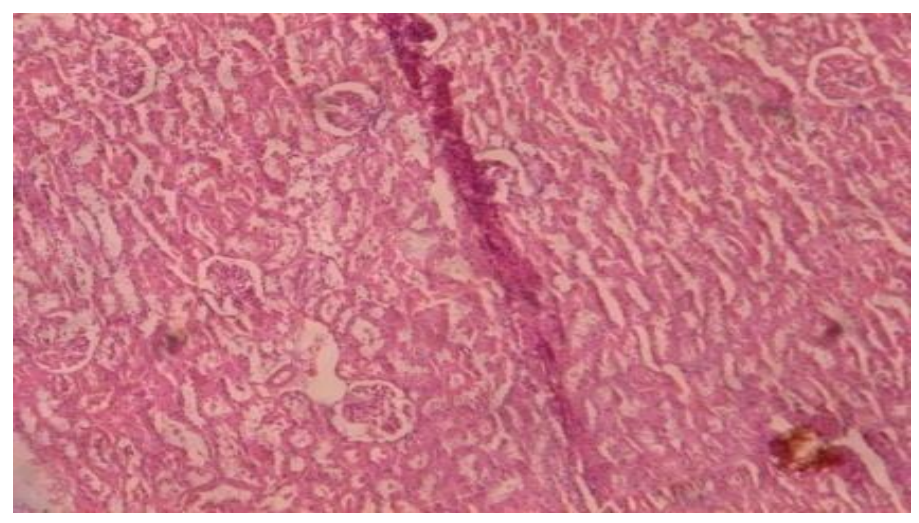

Figure 7:-A representative section of $500 \mathrm{mg} / \mathrm{kg} /$ day $A q . E S B H$ pretreated the kidney section, EG-intoxicated rat kidney at x400 magnification, Haematoxylin and Eosin stain -EG treatment showing some degree of mesengial proliferation (MP) with mild hydropic tubular degeneration (TD) and mild tubular cast (MTC) interposed with normal proximal convoluted tubules (PC) and distal convoluted tubules (DC)

\section{Conclusion:-}

The presented data indicate that administration of ethanolic and aqueous seed extracts of Benincasa hispida at dose levels of $250 \mathrm{mg}$ and $500 \mathrm{mg} / \mathrm{kg}$ body weight to the rats with ethylene glycol induced nephrolithiasis reduced the formation regarding antinephrolithic activity of the plant. Exact mechanism underlying this effect is not clear but apparently related to antioxidant effect and lowering of stone forming constituents. Hence further research was suggested to explore the exact pharmacology of the drug and the study was closed with delight.

\section{Acknowledgement:-}

The authors are sincerely thanks to Vinayaka Mission's University, Salem, Tamil Nadu, India for providing experimental facilities to carry out the work.

\section{Bibliography:-}

1. Coe FL, Evan A, Worcester E. Kidney stone disease. J Clin Invest. 2005: 115: 2598-2608.

2. Kopp JB, Miller KD, Mican JA. et al. Crystalluria and urinary tract abnormalities associated with indinavir. Ann Intern Med. 1997: 127: 119-125.

3. Robertson WG, Hughes H. Epidemiology of urinary stone disease in Saudia Arabia. In: Ryall R, Bais R, Marshall VR, Rofe AM, Smith LH, Walker VR eds. Urolithiasis 2. New York and London: Plenum Press. 1994: 453-5.

4. Reitman S \& Frankel S. A colorimetric method for the determination of serum glutamic oxalacetic and glutamic pyruvic transaminases. Amer. J. Clin. Pathol. 1957: 28: 56-63.

5. M Mohanasundari, M Sabesan\& S Sethupathy. Renoprotective effect of grape seeds extract in ethylene glycol induced nephrotoxic mice. Indian Journal of Experimental Biology. 2005: 43: 356-59

6. Lowry OH, Rosebrough N J, Far AL, R. J. Randall. Protein measurement with the folin phenol reagent. J. Biol. Chem. 1951: 173: 265-75.

7. Singh. N.P. In: Flora of Eastern Karnataka. Vol. I, 1st edn., Mittal Publications, Delhi: 1988: 141-42.

8. Yoganarasimhan, S.N. In: Medicinal Plants of India-Tamil nadu. Vol II, Cyber Media, Bangalore: 2000: 276.

9. Nadkarni's. Indian Materia Medica. 1995: 1: 185-186.

10. Kirtikar and Basu. Indian Medicinal Plants. 1985: 2: 1127-28.

11. Zulfkar Latief Qadrie et. al., Antinociceptive and anti-pyretic activity of Benincasa hispida (Thunb.) Cogn. inWistar albino rats. Pak. J. Pharm. Sci. 22:3: 2009: 287-90.

12. Choubey Ankur, Parasar Amarchand, Choubey Aadarsh, Iyer Deepa, Pawar R S, Patil UK. Potential of medicinal plants in kidney, gall and urinary stones. Int J Drug Dev \& Res. 2: 2: 2010: 431-44.

13. Qadrie et. al., Free radical scavenging and nephroprotective activity of Benincasa hispida (Thunb) Linn. against gentamicin induced nephrotoxicity in rats. Asian Journal of Pharmaceutical Research and Development. 1:3: 2013: 41-47.

14. Anbu Jeba, Sunilson, P. Jayaraj, M. Syam Mohan, A. Anita Gnana Kumari, R. Varatharajan. Antioxidant and hepatoprotective effects of the roots of Hibiscus esculentus Linn. International Journal of Green Pharmacy. 2008: $200-203$. 